\title{
High potential of tellurite bioremediation by moderately halophilic Staphylococcus xylosus
}

\author{
Mahboubeh Soleimani Sasani ${ }^{1}$ (D) Siamak Heidarzadeh ${ }^{2} \cdot$ Mohammad Reza Zolfaghari $^{3} \cdot$ Mohammad Soleimani $^{4}$. \\ Sahar Serajian ${ }^{2}$
}

Received: 14 March 2020 / Accepted: 25 June 2020 / Published online: 6 July 2020

(c) Springer Nature Switzerland AG 2020

\begin{abstract}
The use of bacteria has been considered as a suitable alternative for metalloids remediation. We isolated 84 telluriteresistant bacteria, and characterized tellurite-resistant and tellurite-reducing bacterial strains from samples collected in Iran. We report here a halophilic Gram-positive strain can tolerate and accumulate equal to $26.39 \mathrm{mM}(6598.66 \mu \mathrm{g} / \mathrm{ml})$ concentrations of potassium tellurite from media. This strain were identified according to the $16 \mathrm{~S} r \mathrm{rNA}$ gene sequence as Staphylococcus xylosus. Here we show for the first time that $\mathrm{S}$. xylosus can be efficiently remediate $\mathrm{K}_{2} \mathrm{TeO}_{3}$. Cell aggregation in the presence of tellurite was visually observed by colony color changes to black in media. Reduction of Te to $\mathrm{Te}^{0}$ determined with the spectrophotometric measurement method and sodium diethyldithiocarbamate trihydrate reagent (DDTC, A340nm). In order to provide high tellurite remediation, the optimum growth conditions of this bacterium were determined. The best terms are included $0.4 \mathrm{mM}$ of oxyanion, $40^{\circ} \mathrm{C}$ growth temperature, $\mathrm{pH} 6-8,400 \mathrm{mM} \mathrm{NaCl}$, and 50 RPM under aerobic conditions. Resistant to tellurite and a high level of tellurite reduction by S. xylosus might be interesting for further industrial applications.
\end{abstract}

Keywords Bioreduction · Bioremediation · Contaminated site $\cdot$ Tellurite $\cdot$ Tellurite-reducing bacteria $\cdot$ Tellurite resistance

\section{Introduction}

Tellurium $\left(\mathrm{Te}^{0}\right)$ as a rare metalloid is a member of the group 16 of the Periodic Table which its biological role hasn't been determined yet [1, 2]. The tellurium oxyanion tellurite are well-known for their extremely toxicity for most bacteria and comparatively uncommon in the environment, they can be detectable at high concentrations specially near waste discharge fields as well as widespread in soil, silt, and wastewater that they have been considered serious environmental pollutants [3-5]. Utilization of tellurium, which has been used enormously in metallurgy, electronics, and applied chemical industries, is increasing highly harmful redox state of this elemental form, the oxyanion tellurite $\left(\mathrm{TeO}_{3}{ }^{2-}\right)[6,7]$. However, tellurium's toxicity in human is not explored as in others but more than $4 \mathrm{mM}$ $(1 \mathrm{mg} / \mathrm{ml}$ ) tellurite concentration is highly toxic to prokaryotic and eukaryotic cells $[2,8]$.

Environmentally, tellurite $\left(\mathrm{TeO}_{3}{ }^{2-}\right)$ is most abundant and its toxicity has been to a large extend associated to act as a strong oxidizing agent [4]. The production of reactive oxygen species (ROS) is another hypothesis [9].

Electronic supplementary material The online version of this article (https://doi.org/10.1007/s42452-020-3149-6) contains supplementary material, which is available to authorized users.

$\triangle$ Mahboubeh Soleimani Sasani, mah.sImn@yahoo.com | ${ }^{1}$ Department of Microbiology and Microbial Biotechnology, Faculty of Life Sciences and Biotechnology, Shahid Beheshti University, Tehran, Iran. ${ }^{2}$ Department of Microbiology and Virology, School of Medicine, Zanjan University of Medical Sciences, Zanjan, Iran. ${ }^{3}$ Department of Microbiology, Qom Branch, Faculty of Basic Sciences, Islamic Azad University, Qom, Iran. ${ }^{4}$ Tasnim Biotechnology Research Center (TBRC), Faculty of Medicine, AJA University of Medical Sciences, Tehran, Iran. 
Interestingly, production of ROS is enhanced by conditions such as drought, salt, and temperature stresses, as well as by the combination of these conditions $[1,10]$. On the other hand, some investigation has been recommended thiol biochemistry and metabolism probably play a major role in tellurite toxicity and also tolerance of bacteria to this oxyanion $[11,12]$.

Hitherto, the tellurite toxicity's molecular basis remains debatable. It has been suggested that generating non-functional proteins occurs in replacement $S$ by $\mathrm{Te}$ in some amino acids $[5,13]$. The tellurite resistance mechanisms in bacteria have been proposed as the non-enzymatic or enzymatic reduction of tellurite to amorphous elemental tellurium which results in immobilization and detoxification [1, 14]. Insoluble elemental tellurium found as extracellular or intracellular black inclusions in some bacterial-selective growth media [1, $15,16]$.

Accumulation of Toxic oxyanions such as tellurite in near of waste discharge sites has expected to increase over water and soil contamination [7, 17]. Today, the technologies of microbial bioremediation of toxic compounds and wastewater purification are becoming more popular [18]. Although rare in the bacteria, tellurite resistance occurs quite naturally in Corynebacterium diphtheriae, Streptococcus faecalis, some of the strain of genus Staphylococcus and some species of aerobic phototrophic bacteria [19]. Alternatively halophilic and halotolerant microorganisms could be contemplated appropriate candidates for biotransformation and bioremediation of toxigenic metals due to their capability of growth in high concentration of ions [17]. Resistance to tellurite has been reported in both Gram-positive and Gram-negative bacteria as well as anaerobic and aerobic bacteria $[2,17,20,21]$.

Bacteria that are resistant to tellurite commonly decrease the toxicity and exchange it to elemental tellurium $\left(\mathrm{Te}^{0}\right)$ which gather as black shade intracellular residue. Investigating the molecular mechanisms implying tellurite resistance mechanism is considerable interest in the application of bioremediation $[6,8,22]$. Since tellurite is toxic and environmentally important, determining tellurite-resistant bacteria, and moderately halophilic bacteria for bioremediation of polluted region with tellurite oxyanions is a very interesting issue for researchers $[4,17]$.

The aim of this study was a successful attempt to isolation, characterization and identification the microorganisms capable of transforming toxic $\mathrm{TeO}_{3}{ }^{2-}$ into non-toxic elemental tellurium and to investigate their ability in tellurite removal from contaminated sites for potential biotechnological applications. These bacteria were retrieved from samples picked in dyeing and weaving industrial wastewater evacuated in extreme environment likely dry, heat and salty desert.

SN Applied Sciences

\section{Materials and methods}

\subsection{Isolation, characterization and culture conditions of industrial wastewater tellurite-resistant bacteria}

In total, 84 tellurite resistant bacteria were isolated from 15 environmental samples of wastewater, sediments around the factories, and residue waters in washing tankers were collected of Iran during the summer. Samples were enriched for tellurite resistant bacteria using Luria-Bertani culture media (Merck) [1]. Suspension of Isolated strains comprising nearly $1.5 \times 10^{8} \mathrm{CFU} \mathrm{ml}^{-1}$ was grown routinely in $\mathrm{LB}$ medium with different $\mathrm{K}_{2} \mathrm{TeO}_{3}$ concentrations of $0.4-36 \mathrm{mM}\left(100-9000 \mathrm{\mu g} \mathrm{ml}^{-1}\right)$, at $37^{\circ} \mathrm{C}$ with agitation at $100 \mathrm{rpm}$ for 1 day $(24 \mathrm{~h})$. All tests were performed at least in triplicate [23]. Pure cultures with the highest resistance to tellurite carried in Tryptic soy broth (TSB) media with $20 \%$ glycerol, allowing the bacteria stored in $-20^{\circ} \mathrm{C}$ for 6 months.

After purification, the morphology of all isolated bacteria utilizing a low voltage electronic microscope, Gram-reaction, colony and cell morphology and motility were determined as demonstrated by Arenas et al. [1]. Growth curves as well as progression parameters such as optimal temperature and range, $\mathrm{pH}$, Agitation and different $\mathrm{NaCl}$ concentrations range $(0-20 \% \mathrm{w} / \mathrm{v})$ (Merck) was determined for each isolate as described previously $[1,17,23]$. Other physiological and biochemical characterizations of selected tellurite-resistant bacteria likely Catalase, Oxidase, Voges-Proskauer (VP) test, Enzyme activity etc., were determined [24]. Further analyses were accomplished at the respective strain's optimal growth parameters.

\subsection{Identification of QWTm ${ }_{6}$ tellurite-resistant bacteria}

For identification the accurate isolates, the linear amplification using DNA extraction kit (DNP ${ }^{\mathrm{Tm}}$ Kit, Cinnagene Inc., Iran) of their 16S rRNA gene was applied using the following the manufacturer's recommended procedure and universal primers (8-27F-5'-AGAGTTTGATCCTGGCTCAG-3' and 1492R-5'-GGTTACCTTGTTACGACTTC-3' and 1541R-5'-AAG GAGGTGATCCAGCCGCA-3') $[25,26]$. The reaction mixture was incubated at $94^{\circ} \mathrm{C}$ for $5 \mathrm{~min}$ ( 1 cycle) followed by 30 cycles of $30 \mathrm{~s}$ at $94^{\circ} \mathrm{C}$, annealing for $1 \mathrm{~min}$ at $57^{\circ} \mathrm{C}(30$ cycles), and extension for $1 \mathrm{~min}$ at $72^{\circ} \mathrm{C}$ (30 cycles). Then, the reaction mixture was kept for $10 \mathrm{~min}$ at $72{ }^{\circ} \mathrm{C}$, cooled to $4{ }^{\circ} \mathrm{C}$, and $\mathrm{PCR}$ product purified by $1 \%(\mathrm{w} / \mathrm{v})$ agarose gel and sequenced by Seqlab Laboratory (Germany) [27]. 
Phylogenetic trees of the amplified sequence of $16 \mathrm{~S}$ rRNA of S. xulosys with closely related Staphylococcus were formed utilizing the neighbor-joining technique as executed in the CLC Sequence Viewer version 6.5.1. Software.

\subsection{Determination of tellurium oxyanion tolerance and antimicrobial disk assay}

Agar diffusion method was used to measure the resistance of QWTm 6 strain to toxic oxyanion of tellurite [24]. After pouring molten nutrient agar in addition to various concentrations of $\mathrm{K}_{2} \mathrm{TeO}_{3}$ of $0.1 \mathrm{mM}$ up to $36 \mathrm{mM}$ (25-9000 $\mathrm{m} \mathrm{m} \mathrm{m}^{-1}$ ) into plates, bacterial suspension (adjusted to $1.5 \times 10^{8} \mathrm{CFU} \mathrm{ml}^{-1}$ ) was inoculated on every plate and then incubated at $37^{\circ} \mathrm{C}$ for 7 days with shaking.

Minimum inhibitory concentration (MIC) for tellurite was evaluated. Each plate was assembled in triplicates. Overnight cultures of elected strains were diluted with LB medium, and were spread on LB-agar (2\%) plates [28]. Antibiotic disks were put in the middle of the plates, growth inhibition zones were measured after incubation $24 \mathrm{~h}$ at $37^{\circ} \mathrm{C}[29]$.

\subsection{Features impacting or influencing tellurite removal}

Capability of tellurite removal by the strains were evaluated at varied $\mathrm{pH}$ values of $5-11$, vigorous agitation (50-200 rpm), and temperatures ranging from 5 to $60^{\circ} \mathrm{C}$ in basal medium supplemented with $0.5 \mathrm{mM}$ potassium tellurite. To identify the efficacy of diverse concentration of sodium chloride (Merck) on tellurite removal, $\mathrm{NaCl}$ (50-450 mM) were included to the basal medium.

To estimate the effect of initial tellurium concentration, cultures that incubated for 1 day were diluted 1:100 with new $L B$ medium and at the same time grown with shaking (140 rpm), $37^{\circ} \mathrm{C}$. Then, $\mathrm{K}_{2} \mathrm{TeO}_{3}(0.1,0.2,0.3,0.4,0.4,0.5,0.6$, $0.7,0.8,0.9$ and $1 \mathrm{mg} \mathrm{ml}^{-1}$ ) was added and aliquots were picked at various time periods over $144 \mathrm{~h}$ and for $10 \mathrm{~min}$ centrifuged at 10,000 rpm. The method for quantification of other remaining extracellular tellurite with the aid of Supernatants was colorimetric DDTC-method (340 nm) demonstrated by Turner et al. [17, 30]. All experiments were done in triplicate.

\subsection{Statistical analysis}

The normality of data on Tellurite Concentration (TC) was tested using Kolmogorov-Smirnov in SPSS software (IBM, version 20) and the result showed that data were not normally distributed $(P=0.000)$. Therefore, the significant difference in tellurite concentration among 9 groups was tested using One-Way ANOVA with SNK post-hoc test at the significance level of 0.0 (Table S1). The variation of TC as dependent variable over time was tested using the linear regression. Additionally, strongly autocorrelated time series analysis was performed for predicting tellurite bioreduction for the next 14 days.

\section{Results and discussion}

\subsection{Isolation and identification of QWTm 6 tellurite-resistant bacteria}

Among 84 tellurite-resistant bacteria isolated from various environmental source, $\mathrm{QWTm}_{6}$ which separated from dyeing textile industrial wastewater near salt desert located in Qom, Iran, showed compatible growth in LB-agar in the presence of $\mathrm{K}_{2} \mathrm{TeO}_{3}$. This strain because of its high levels of tellurite resistance and reduction the toxicant, was selected for further analysis to estimate its capacity to resist and reduce tellurite under different temperatures and initial tellurite concentrations (Table 1). The minimum inhibitory concentration of $\mathrm{QWTm}{ }_{6}$ was determined. Based on MICs, QWTm ${ }_{6}$ strain tolerated relatively high concentrations of tellurite, $26 \mathrm{mM}$. QWTm 6 is a Gram-positive coccus whose optimal growth temperature was $37^{\circ} \mathrm{C}$. Basic morphological traits in an optimal growth situation followed by tellurite tolerance of the $\mathrm{QWTm}_{6}$ strain and optimal growth temperature are shown in Table 1.

Biochemical and physiological characterizations of the $\mathrm{QWTm}_{6}$ strain was accomplished (Table S2). Analyzing the capability of growth in the presence of various $\mathrm{NaCl}$ concentrations $\mathrm{QWTm}_{6}$ grew in up to $20 \% \mathrm{NaCl}$. Table S3 concludes some antibiotic resistance characteristics of the $\mathrm{QWTm}_{6}$ strain.

After determination and comparison of the 16S rRNA gene sequence of the $\mathrm{QWtm}_{6}$ strain with those existed in the NCBI database, phylogenetic trees were built. The results represented that $\mathrm{QWtm}_{6}$ strain was similar to Staphylococcus genus (Fig. 1).

For studying tellurite-uptake in tellurite-resistant bacteria, S. xylosus strain QWTm 6 was inoculated into fresh LB medium. When the bacteria $\mathrm{OD}_{600}$ were $\sim 0.8$, the culture was adjusted with various tellurite concentrations (Fig. 2) and the present tellurite in the supernatants were evaluated as described above [30]. Figure 2 exhibits that in $24 \mathrm{~h} \sim 62 \%$ of the toxic oxyanion was eliminated from the culture medium by $S$. xylosus strain $\mathrm{QWTm}_{6}$.

\subsection{Determination of optimal growth condition of QWTm 6 tellurite-resistant bacteria}

Optimal conditions for isolates including incubation temperature, $\mathrm{pH}$, Agitation and salt concentrations were 
determined (Fig. 3a-d). These conditions had remarkable impact on potassium tellurite removal and the maximum removal in $\mathrm{QWTm}_{6}$ strain took place at $\mathrm{pH}$ value of 8.0, $40{ }^{\circ} \mathrm{C}$, and $50 \mathrm{rpm}$.

The maximum removal efficiency in $\mathrm{QWTm}_{6}$ strain at $\mathrm{pH}$ value of 8 was $97 \%$. At pHs less than 6 and more than 9, the quantity of potassium tellurite removal was significantly reduced (Fig. 3a). Te removal in temperature of $40{ }^{\circ} \mathrm{C}$, and shaking at $50 \mathrm{rpm}$ were, $46 \%$ and $97 \%$, respectively (Fig. 3b, c). Temperature decreasing and increasing the agitation reduced the elimination of Te from the culture media compared to the optimal growth conditions.

To define the effects of different salt concentrations on the potassium tellurite removal capacity of the strains, $\mathrm{NaCl}$ was added to the medium in the concentrations of 250-450 mM. Maximum potassium tellurite elimination in $\mathrm{QWTm}_{6}$ strain was seen in the presence of $400 \mathrm{mM}$ $\mathrm{NaCl}$ (Fig. 3d). When the concentrations of $\mathrm{NaCl}$ raised in culture media, the removal of potassium tellurite was attained, however, increasing the concentrations of salt from $400 \mathrm{mM}$ caused decline in the potassium tellurite removal by the $\mathrm{QWTm}_{6}$ strain.

Using linear regression analysis, it was found that Tellurite concentration in determination of different concentrations effect of tellurite on their removal by strain $\mathrm{QWTm}_{6}$ experiments is equal to " $0.844 \mathrm{mM}-0.001$ Time" (mM: Tellurite molarity, $\mathrm{R}^{2}=0.61, P=0.051$ ). This model represents the linear relationship between the independent and dependent variables alternations at time. Time series forecasting based on a model fitted to present and past observations shows no difference between observed and expected data according other investigations [31, 32]. In general, we see a decreasing trend in the TC (tellurite concentration) pattern, and accordingly, best bioreduction occurs in $0.4 \mathrm{mM}$ tellurite and in this concentration the tellurite content will be zero at the end of an 8-day bacterial exposure (Fig. 4).

According to morphological and biochemical assays Strain $\mathrm{QWTm}_{6}$ belong to genera Staphylococcus and relying on $16 \mathrm{~S}$ rRNA nucleotide gene sequences, $\mathrm{QWTm}_{6}$ strain was assigned to the genera S. xylosus (Table 1, Fig. 1). MIC assays in liquid media supported tellurite-tolerance outcomes. Strain $\mathrm{QWTm}_{6}$ was exhibited high MICs for tellurium (MIC $26 \mathrm{mM}$ equal to $6599 \mathrm{\mu g} \mathrm{ml}^{-1}$ ). Considering of high tellurite MICs, Isolated Staphylococcus strain $\mathrm{QWTm}_{6}$ possesses best tellurite-reducing and the highest tellurite-resistance ability which is not yet reported among the bacteria and the genera Staphylococcus. Arenas et al. isolated some Staphylococcus bacteria which best MiCs among them was $525 \mathrm{\mu g} \mathrm{ml}^{-1}$ [1]. In fact, QWTm ${ }_{6}$ strain being able to thrive at concentrations $\sim$ tenfold higher than their isolated bacteria or $\sim$ sevenfold compare to Shakibaie, et al. results [33]. 


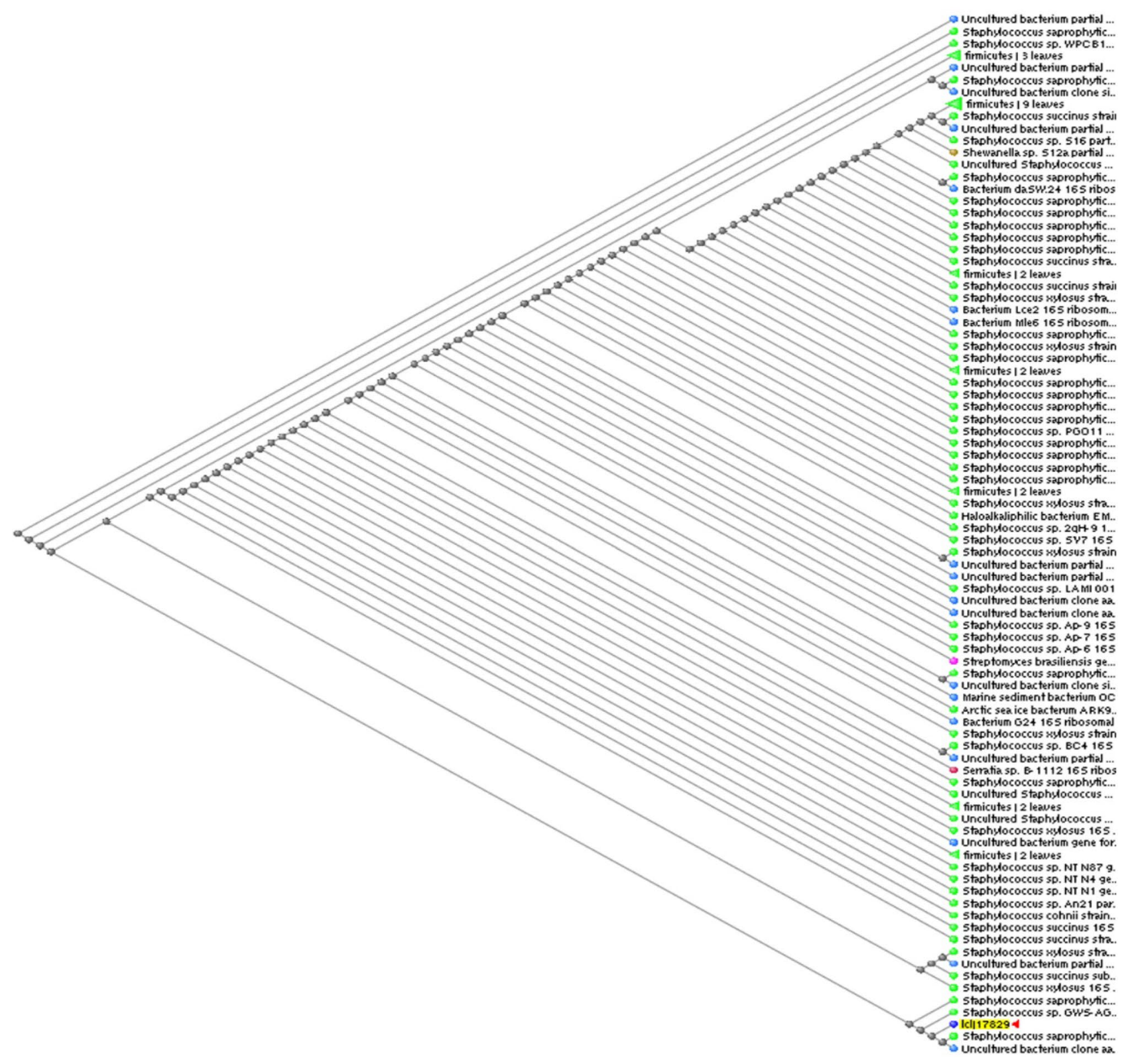

Fig. 1 16S rRNA gene sequence-based phylogenetic trees of the QWTm 6 strain among members of cocci Gram-positive bacteria. The neighbor-joining method was utilized for construction of tree

Generally, Gram-positive bacteria likely Staphylococcus display higher levels of tellurite resistance than Gram-negative microorganisms [13] but No tellurite-resistant S. xylosus were reported in earlier studies. Compared to sensitive bacteria like E. coli with $1 \mathrm{mg} \mathrm{ml}^{-1}$ tellurite MIC [34], high level tellurite resistance (MICs $>500 \mathrm{mg} \mathrm{ml}^{-1}$ ) was distinguished for $61.90 \%$ of the isolates (52 out of 84 isolates).

For determination of tellurite uptake using diethyldithiocarbamate (DDTC) tellurite method, it was observed that QWTm6 strain can reduce tellurite to $T \mathrm{~T}^{0}$ for just the first $12 \mathrm{~h}$ of a $24 \mathrm{~h}$ culture so it has high effectiveness in tellurite detoxification. Additionally, almost $\sim 90 \%$ of the tellurite originally stock in the culture medium was eliminated by QWTm6. In this method, the tellurite concentration in the culture supernatant at different intervening periods was measured using DDTC (Merck, Germany) reagent [30]. Our result is similar to other investigations which tellurite uptake is very quickly [35]. Instead, some research has shown that removing of tellurium into the bacterium is very slowly [1].

As potassium and sodium are two essential requirement for the activity of enzymes and mostly pumps in halophiles, it appears that enhancement of toxic metal tolerance and removal happen due to these elements [24]. 
Tellurite Concentration (mM)

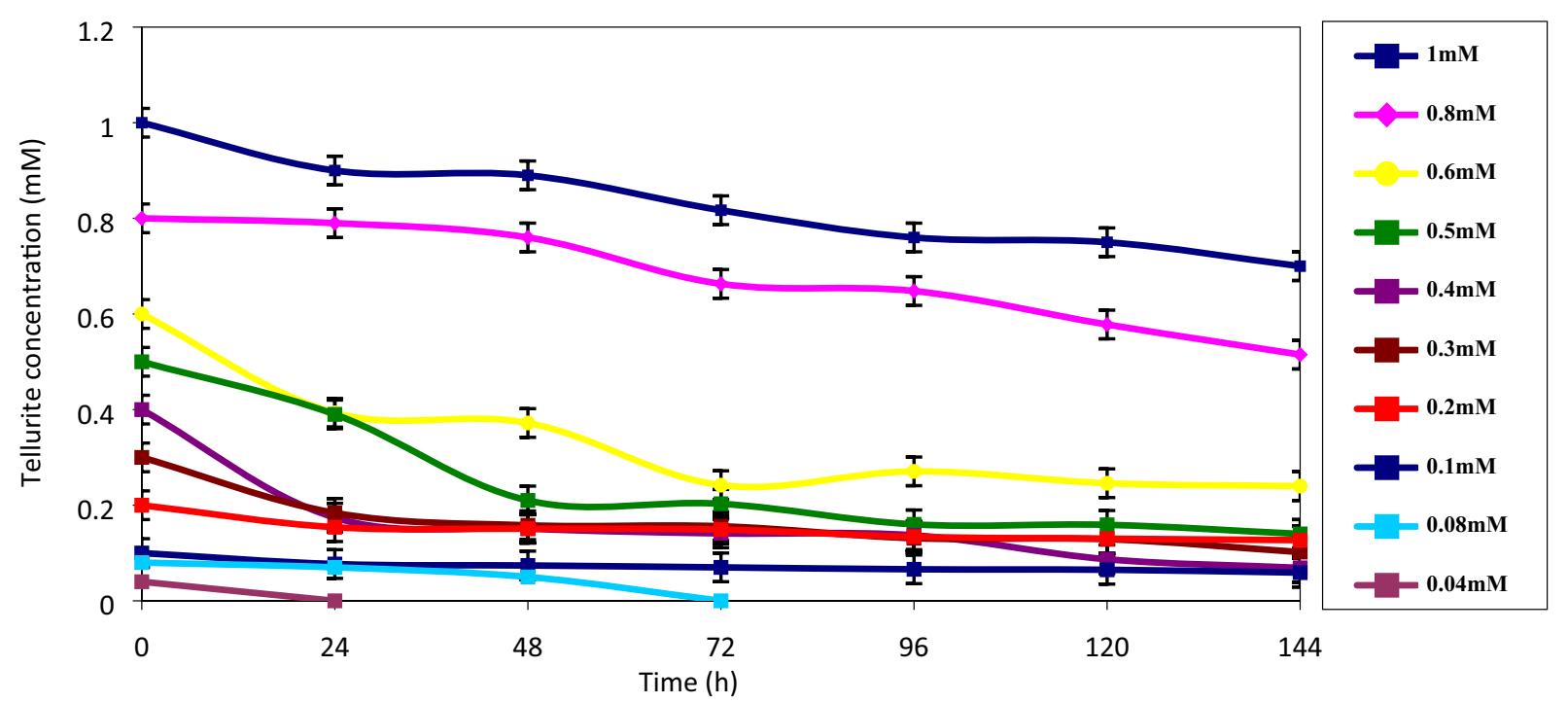

Fig. 2 Different concentrations effect of tellurite on their removal by strain $\mathrm{QWTm}{ }_{6}$ in $\mathrm{LB}$ broth medium $\left(\mathrm{T}=37^{\circ} \mathrm{C}, \mathrm{pH}=8 \pm 0.2, \mathrm{rpm}=50\right.$, Absorbance $340 \mathrm{~nm}$ ). Reduction was monitored after 24, 48, 72, 96, 120, $144 \mathrm{~h}$

$\mathrm{QWTm}_{6}$ strain removes Te oxyanion in the lack of any salts and over a range of moderate $\mathrm{NaCl}$ concentrations (up to $450 \mathrm{mM}$, Fig. 3d). In these circumstances, the capability of this halotolerant microorganism to eliminate tellurite in the existence of a wide variety of salt concentrations, $\mathrm{pH}$ and temperature makes it a worthy candidate for biotransformation and bioremediation of toxic metals and metalloids $[2,24,36]$. According to investigations, thermal and salt areas, has provided cultures of bacteria display very high-level resistance to tellurite which was consistent with the results of our experiments [9].

Prominently, QWTm 6 strain exhibited a strong black color and black colony in broth and solid media, respectively. This appearance can occur when Te accumulates as black intracellular residue which previously have been shown in a variety of investigations and seems to be one of the main ways to tellurite detoxification in microorganisms. Blackening of culture indicate the presence of elemental Te accumulation in cell as well as bioreduction $[7,12,22]$.

According to investigations, existence of heavy metals could induce and enhance bacterial antibiotic resistance [37]. These reports highlight increasing risks to public health and environmental contamination which would be the most important result of the experiments [37]. Furthermore, co-existence of heavy metal and antibiotic can change their each impact on the expanse of pollution, in addition to biological removal of pollutants, which can affect bioremediation and bioreduction processes [29]. On the other hand, antibiotic-resistant bacteria, known as 'bio-indicator', have received much attention for the evaluation and detection of environmental pollution [18]. We have derived a Regression Equation for the evaluation of a TC reduction change point in a linear regression. Through analyzing our bioremediation data, we have elucidated an Equation to be an effective tool in estimating enhancement of tellurite removal from wastewater during the time of bacterial exposure.

\section{Conclusion}

Considering the dangers of utilizing metals and metalloids in industries and their release into the environment, the use of bacteria has been proposed as an appropriate and performance choice for potassium tellurite bioremediation.

\section{SN Applied Sciences}


Fig. 3 a Effect of $\mathrm{pH}$ values on tellurite removal by $\mathrm{QWTm}_{6}$ strain in . LB broth medium containing $0.4 \mathrm{mM}$ potassium tellurite after $24 \mathrm{~h}$ $\left(\mathrm{T}=37^{\circ} \mathrm{C}, \mathrm{rpm}=50\right)$. b Temperature effect on tellurite removal by $\mathrm{QWTm}_{6}$ strain in LB broth medium containing $0.4 \mathrm{mM}$ potassium tellurite after $24 \mathrm{~h}(\mathrm{pH} 7, \mathrm{rpm}=50)$. c Shaking incubator effect on tellurite removal by QWTm $_{6}$ strain in LB broth medium containing $0.4 \mathrm{mM}$ potassium tellurite after $24 \mathrm{~h}\left(\mathrm{~T}=37^{\circ} \mathrm{C}, \mathrm{pH}\right.$ 7). $\mathbf{d}$ Effect of various salt concentration $(\mathrm{mM})$ on tellurite removal by $S$. xylosus strain $\mathrm{QWTm}_{6}$ in basal medium containing $0.5 \mathrm{mM}$ potassium tellurite $(\mathrm{pH} 7.5)$

The capacity of the moderately halophilic QWTm ${ }_{6}$ strain belonging to Staphylococcus genus, to grow aerobically in the presence of high concentrations of the toxic oxyanion tellurite and to reduce it into elemental tellurium $\left(\mathrm{Te}^{0}\right)$ was determined. The estimated MIC value $(26.39 \mathrm{mM}$ or $6598.66 \mathrm{\mu g} / \mathrm{ml}$ ) of $\mathrm{TeO}_{3}{ }^{2-}$ oxyanions for aerobic growth of QWTm ${ }_{6}$ strain highlighted its feature to tolerate high concentration of this toxic oxyanion, as compared to other Gram-positive bacteria previously described as tellurite tolerant and/or resistant microorganisms. Tellurite bioassays indicate that the bacteria were about 2 to 3 -times more resistant to tellurite than the best literature reports for the same genus [17] or other Gram-positive bacteria [38].

The result clearly demonstrates that by use of $S$. xylosus $\mathrm{QWTm}_{6}$ which isolated from an extreme environmental conditions such as high temperature and salt desert (Qom salt lake, Iran), we can eliminate $\sim 62 \%$ of the toxic oxyanion/24 $\mathrm{h}$ from the culture medium. $S$. xylosus $\mathrm{QWTm}_{6}$ bacteria could perform tellurite reduction under salinity conditions upper than $\% 20$.

As the S. xylosus is a safe bacterium for commercial application and its pathogenicity in human and veterinary medicine is scarce [39], the present study demonstrated that aerobically grown $\mathrm{QWTm}_{6}$ strain can be utilized as a good candidate for "green technology" in bioremediation of highly polluted sewage instead of conventional cleanup technologies. (a)

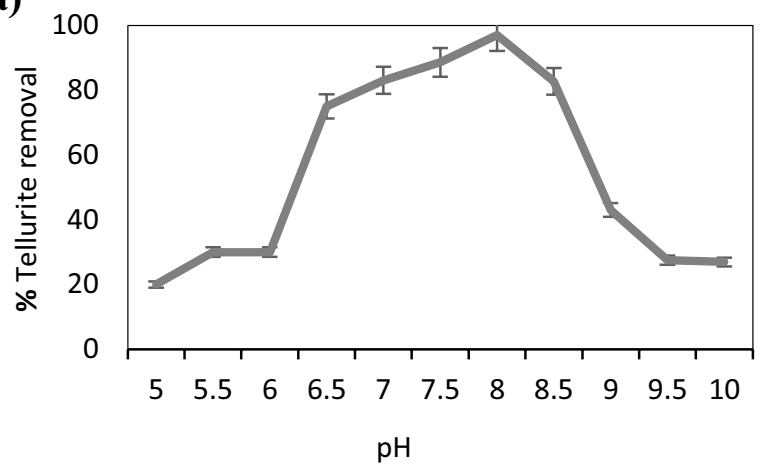

(b)

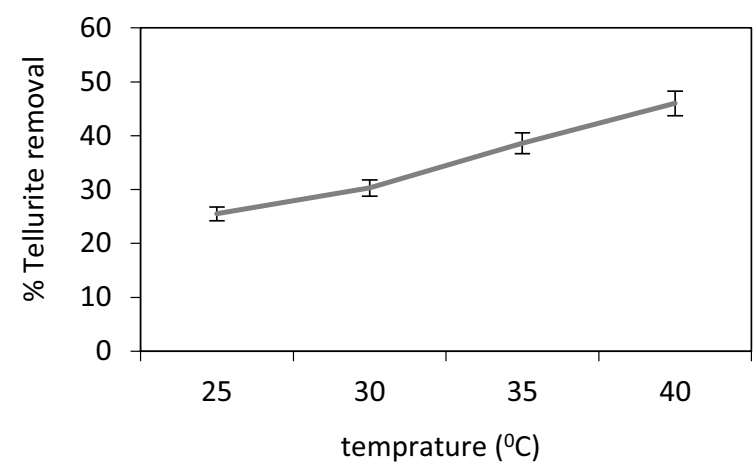

(c)

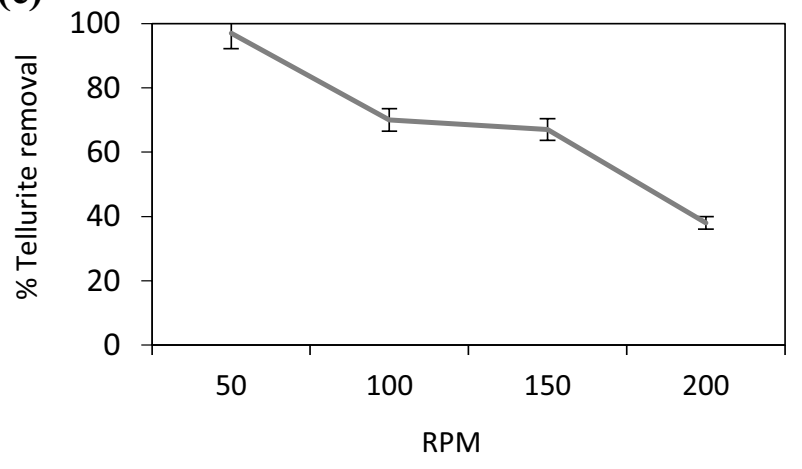

(d)

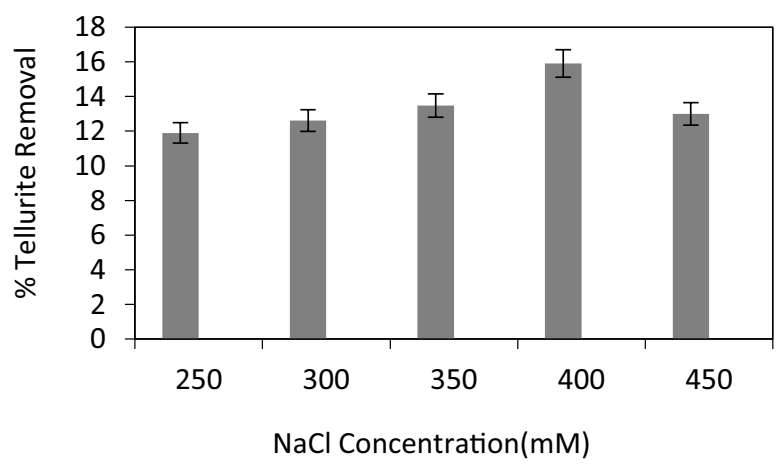




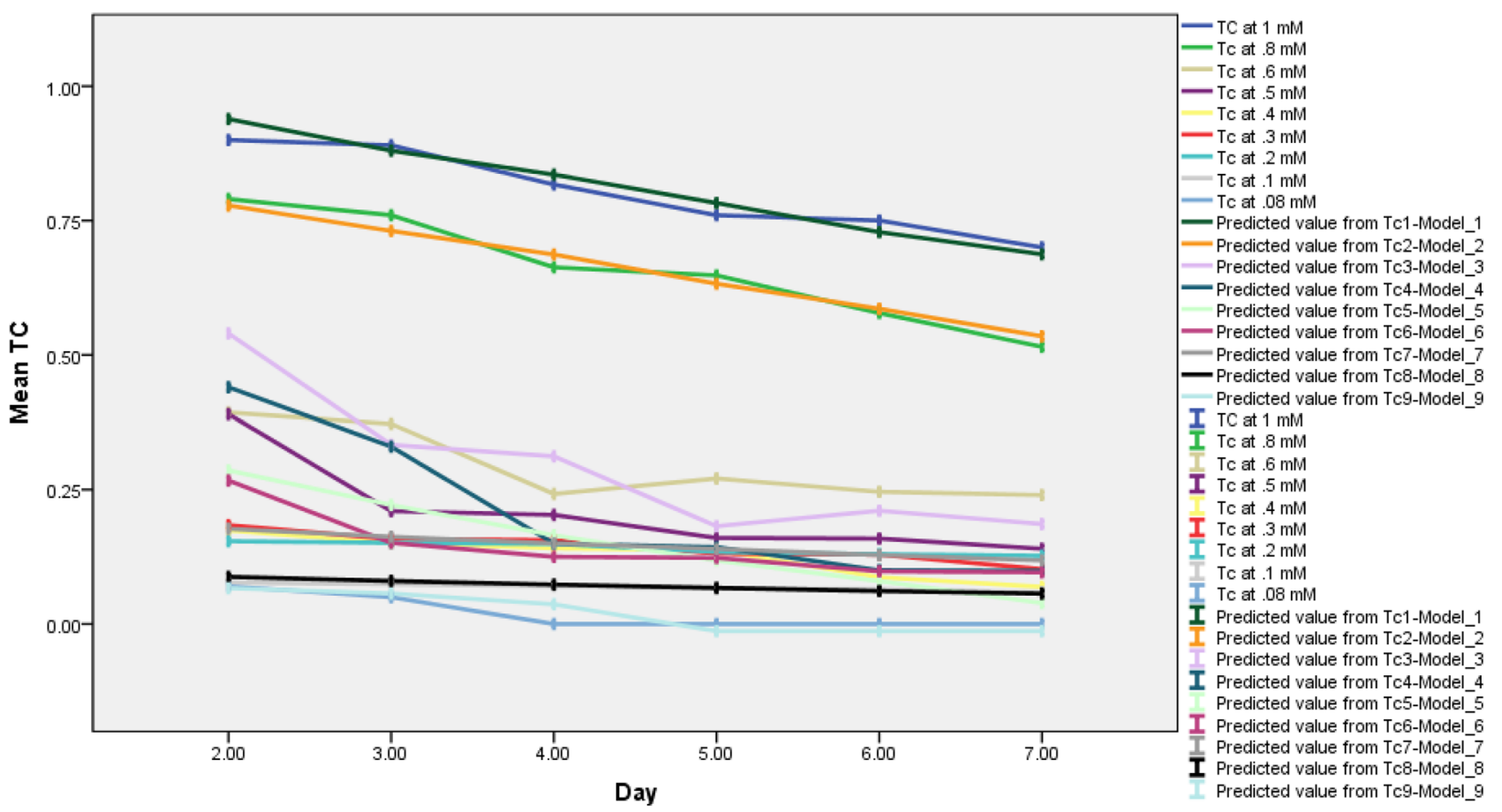

Fig. 4 Time-series forecast plots of tellurite concentrations (TC) from 8 to 14 days and compare with tellurite concentrations experiments (1-7 days)

Acknowledgements Part of this article was presented at The 16th International and Iranian Congress of Microbiology, Tehran, Iran, 2015. The corresponding author is grateful for the underpinning support of colleagues at Qom Azad University, Iran.

Author contributions MSS designed and performed the research experiments, analyzed data, wrote the manuscript and Corresponding author, SH and SS Co-wrote the paper. MRZ supervised the research and MS advised the research. All authors read and approved the final manuscript.

\section{Compliance with ethical standards}

Conflict of interest The authors declare no conflict of interest associated with this manuscript.

Availability of data and materials All data generated or analyzed during this study are included in this published article.

Consent for publication All of the authors have read and approved to submit it to SN applied science.

Ethical approval Not applicable.

\section{References}

1. Arenas FA, Pugin $B$, Henríquez NA, Arenas-Salinas MA, DíazVásquez WA, Pozo MF, Muñoz CM, Chasteen TG, Pérez-Donoso
JM, Vásquez CC (2014) Isolation, identification and characterization of highly tellurite-resistant, tellurite-reducing bacteria from Antarctica. Polar Sci 8(1):40-52. https://doi.org/10.1016/j.polar .2014.01.001

2. Presentato A, Turner RJ, Vásquez CC, Yurkov V, Zannoni D (2019) Tellurite-dependent blackening of bacteria emerges from the dark ages. Environ Chem 16:266-288. https://doi.org/10.1071/ EN18238

3. Rathgeber C, Yurkova N, Stackebrandt E, Beatty JT, Yurkov V (2002) Isolation of tellurite-and selenite-resistant bacteria from hydrothermal vents of the Juan de Fuca Ridge in the Pacific Ocean. Appl Environ Microbiol 68(9):4613-4622. https://doi. org/10.1128/AEM.68.9.4613-4622.2002

4. Chasteen TG, Fuentes DE, Tantaleán JC, Vásquez CC (2009) Tellurite: history, oxidative stress, and molecular mechanisms of resistance. FEMS Microbiol Rev 33(4):820-832. https://doi.org/ 10.1111/j.1574-6976.2009.00177.x

5. Taylor DE (1999) Bacterial tellurite resistance. Trends Microbiol 7(3):111-115. https://doi.org/10.1016/s0966-842x(99)01454-7

6. Turner RJ, Borghese R, Zannoni D (2012) Microbial processing of tellurium as a tool in biotechnology. Biotechnol Adv 30(5):954963. https://doi.org/10.1016/j.biotechadv.2011.08.018

7. Choi W, Ha Y, Gu Y, Lee C, Park J, Jang G, Shin C, Cho S (2019) Microbial tellurite reduction and production of elemental tellurium nanoparticles by novel bacteria isolated from wastewater. J Ind Eng Chem 78:246-256. https://doi.org/10.1016/j. jiec.2019.06.006

8. Ba LA, Döring M, Jamier V, Jacob C (2010) Tellurium: an element with great biological potency and potential. Org Biomol Chem 8(19):4203-4216. https://doi.org/10.1039/C0OB00086H

9. Maltman C, Yurkov V (2019) Extreme environments and highlevel bacterial tellurite resistance. Microorganisms 7(12):601. https://doi.org/10.3390/microorganisms7120601

\section{SN Applied Sciences}


10. Miller G, Suzuki N, Ciftci-Yilmaz S, Mittler R (2010) Reactive oxygen species homeostasis and signalling during drought and salinity stresses. Plant Cell Environ 33(4):453-467. https://doi. org/10.1111/j.1365-3040.2009.02041.x

11. Tremaroli V, Workentine ML, Weljie AM, Vogel HJ, Ceri H, Viti C, Tatti E, Zhang P, Hynes AP, Turner RJ (2009) Metabolomic investigation of the bacterial response to a metal challenge. Appl Environ Microbiol 75(3):719-728. https://doi.org/10.1128/ AEM.01771-08

12. Piacenza E, Presentato A, Zonaro E, Lampis S, Vallini G, Turner RJ (2018) Microbial-based bioremediation of selenium and tellurium compounds. In: Derco J (ed) Biosorption'. IntechOpen, London, pp 117-147. https://doi.org/10.5772/intechopen .72096

13. Pugin B, Cornejo FA, García JA, Díaz-Vásquez WA, Arenas FA, Vásquez CC (2014) Thiol-mediated reduction of Staphylococcus aureus tellurite resistance. Adv Microbiol. https://doi. org/10.4236/aim.2014.44024

14. Ramos-Ruiz A, Sesma-Martin J, Sierra-Alvarez R, Field JA (2017) Continuous reduction of tellurite to recoverable tellurium nanoparticles using an upflow anaerobic sludge bed (UASB) reactor. Water Res 108:189-196. https://doi.org/10.1016/j. watres.2016.10.074

15. Gadd GM (2010) Metals, minerals and microbes: geomicrobiology and bioremediation. Microbiology 156(3):609-643. https ://doi.org/10.1099/mic.0.037143-0

16. Kim D-H, Kim M-G, Jiang S, Lee J-H, Hur H-G (2013) Promoted reduction of tellurite and formation of extracellular tellurium nanorods by concerted reaction between iron and Shewanella oneidensis MR-1. Environ Sci Technol 47(15):8709-8715. https ://doi.org/10.1021/es401302w

17. Amoozegar MA, Ashengroph M, Malekzadeh F, Razavi MR, Naddaf S, Kabiri M (2008) Isolation and initial characterization of the tellurite reducing moderately halophilic bacterium, Salinicoccus sp. strain QW6. Microbiol Res 163(4):456-465. https://doi.org/10.1016/j.micres.2006.07.010

18. Joshi SJ (2016) Microbial biotechnology and environmental bioremediation: challenges and prospects. Open Biotechnol J 10:287-288. https://doi.org/10.2174/1874070701610010287

19. Alavi S, Amoozegar MA, Khajeh K (2014) Enzyme (s) responsible for tellurite reducing activity in a moderately halophilic bacterium, Salinicoccus iranensis strain QW6. Extremophiles 18(6):953-961. https://doi.org/10.1007/s00792-014-0665-6

20. Klonowska A, Heulin T, Vermeglio A (2005) Selenite and tellurite reduction by Shewanella oneidensis. Appl Environ Microbiol 71(9):5607-5609. https://doi.org/10.1128/ AEM.71.9.5607-5609.2005

21. Bajaj M, Winter J (2014) Se (IV) triggers faster Te (IV) reduction by soil isolates of heterotrophic aerobic bacteria: formation of extracellular SeTe nanospheres. Microb Cell Fact 13(1):168. https ://doi.org/10.1186/s12934-014-0168-2

22. Soudi MR, Ghazvini PTM, Khajeh K, Gharavi S (2009) Bioprocessing of seleno-oxyanions and tellurite in a novel Bacillus sp. strain STG-83: a solution to removal of toxic oxyanions in presence of nitrate. J Hazard Mater 165(1):71-77. https://doi.org/10.1016/j. jhazmat.2008.09.065

23. Fuentes DE, Fuentes EL, Castro ME, Pérez JM, Araya MA, Chasteen TG, Pichuantes SE, Vásquez CC (2007) Cysteine metabolismrelated genes and bacterial resistance to potassium tellurite. J Bacteriol 189(24):8953-8960. https://doi.org/10.1128/JB.01252 $-07$

24. Amoozegar MA, Khoshnoodi M, Didari M, Hamedi J, Ventosa A, Baldwin SA (2012) Tellurite removal by a tellurium-tolerant halophilic bacterial strain, Thermoactinomyces sp. QS-2006. Ann Microbiol 62(3):1031-1037. https://doi.org/10.1007/s1321 3-011-0343-1
25. Felske $A$, Rheims $H$, Wolterink $A$, Stackebrandt $E$, Akkermans AD (1997) Ribosome analysis reveals prominent activity of an uncultured member of the class Actinobacteria in grassland soils. Microbiology 143(9):2983-2989. https://doi.org/10.1099/00221 287-143-9-2983

26. Rajendhran J, Gunasekaran P (2011) Microbial phylogeny and diversity: small subunit ribosomal RNA sequence analysis and beyond. Microbiol Res 166(2):99-110. https://doi.org/10.1016/j. micres.2010.02.003

27. Ibeyaima A, Rana J, Dwivedi A, Gupta S, Sharma SK, Saini N, Sarethy IP (2016) Characterization of Yuhushiella sp. TD-032 from the Thar Desert and its antimicrobial activity. J Adv Pharm Technol Res 7(2):32-36. https://doi.org/10.4103/2231-4040.177201

28. Bonificio WD, Clarke DR (2014) Bacterial recovery and recycling of tellurium from tellurium-containing compounds by Pseudoalteromonas sp. EPR 3. J Appl Microbiol 117(5):1293-1304. https://doi.org/10.1111/jam.12629

29. Zhou Y, Xu Y-B, Xu J-X, Zhang X-H, Xu S-H, Du Q-P (2015) Combined toxic effects of heavy metals and antibiotics on a Pseudomonas fluorescens strain $\mathrm{ZY} 2$ isolated from swine wastewater. Int J Mol Sci 16(2):2839-2850. https://doi.org/10.3390/ijms1 6022839

30. Turner RJ, Weiner JH, Taylor DE (1992) Use of diethyldithiocarbamate for quantitative determination of tellurite uptake by bacteria. Anal Biochem 204(2):292-295. https://doi.org/10.1016/00032697(92) $90240-8$

31. Chen D, Fries M, Lyon JM (2003) A statistical method of detecting bioremediation. J Data Sci 1(1):27-41

32. Huang G, Huang Y, Wang G, Xiao H (2006) Development of a forecasting system for supporting remediation design and process control based on NAPL-biodegradation simulation and stepwise-cluster analysis. Water Resour Res. https://doi. org/10.1029/2005WR004006

33. Shakibaie $M$, Adeli-Sardou $M$, Mohammadi-Khorsand T, ZeydabadiNejad M, Amirafzali E, Amirpour-Rostami S, Ameri A, Forootanfar H (2017) Antimicrobial and antioxidant activity of the biologically synthesized tellurium nanorods; a preliminary in vitro study. Iran J Biotechnol 15(4):268

34. Silkina A, Nelson GD, Bayliss CE, Pooley CL, Day JG (2017) Bioremediation efficacy - comparison of nutrient removal from an anaerobic digest waste-based medium by an algal consortium before and after cryopreservation. J Appl Phycol 29(3):13311341. https://doi.org/10.1007/s10811-017-1066-x

35. Maltman C, Yurkov V (2018) Bioremediation potential of bacteria able to reduce high levels of selenium and tellurium oxyanions. Arch Microbiol 200(10):1411-1417

36. Chien CC, Han CT (2009) Tellurite resistance and reduction by a Paenibacillus $\mathrm{Sp}$ isolated from heavy metal-contaminated sediment. Environ Toxicol Chem 28(8):1627-1632. https://doi. org/10.1897/08-521.1

37. Chen S, Li X, Sun G, Zhang Y, Su J, Ye J (2015) Heavy metal induced antibiotic resistance in bacterium LSJC7. Int J Mol Sci 16(10):23390-23404. https://doi.org/10.3390/ijms161023390

38. Presentato A, Piacenza E, Anikovskiy M, Cappelletti M, Zannoni D, Turner RJ (2016) Rhodococcus aetherivorans BCP1 as cell factory for the production of intracellular tellurium nanorods under aerobic conditions. Microb Cell Fact 15(1):204. https:// doi.org/10.1186/s12934-016-0602-8

39. Gozalo AS, Hoffmann VJ, Brinster LR, Elkins WR, Ding L, Holland SM (2010) Spontaneous Staphylococcus xylosus infection in mice deficient in NADPH oxidase and comparison with other laboratory mouse strains. J Am Assoc Lab Anim Sci 49(4):480-486

Publisher's Note Springer Nature remains neutral with regard to jurisdictional claims in published maps and institutional affiliations. 